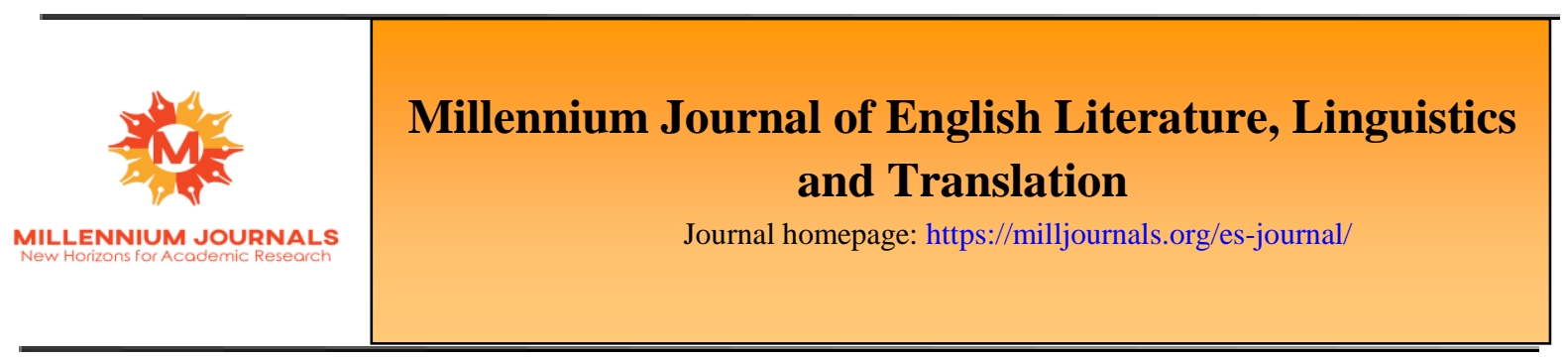

\title{
A Comparison Between Iranian L3 French and German Learners' Perception of Factors Influencing Willingness to Speak English in Language Classrooms: A Mixed Methods Study
}

\author{
Mohammad Bavali \\ Department of Foreign Languages, Shiraz Branch, Islamic Azad University, Shiraz, Iran \\ Asma Siyahi \\ Department of Foreign Languages, Shiraz Branch, Islamic Azad University, Shiraz, Iran \\ https://doi.org/10.47340/mjellt.v1i1.5.2020
}

\begin{abstract}
The present study sought to investigate the effect of learning a third language on learners' willingness to communicate in their second language. The main purpose of the study, however, was to consider the difference between Iranian English/French learners and Iranian English/German learners in their willingness to communicate (WTC) in the second language and to examine the factors influencing their willingness to speak in English. The study benefited from a mixed methodology design comprising both quantitative and qualitative data collection and analysis. The participants of the study were 20 bilingual learners and 40 trilingual learners, including 20 German learners and 20 French learners. They were selected as the sample population based on their performance on the standard test of OPT (Oxford Placement Test). It was an applied research in which a descriptive survey method had been adopted. A (WTC) questionnaire was used for collecting data. The results indicated a significant difference between bilingual and trilingual learners in their willingness to communicate in English. However, no significant difference was detected between trilingual learners. To verify the quantitative findings and to assess the accuracy of their results, interviews were used. Accordingly, a group of German and French learners was invited for interviews. Semi-structured interviews were conducted with twelve L3 learners to examine the factors influencing willingness to communicate in both groups. The qualitative data derived from interviews were analyzed using NVivo software. No significant difference in the factors affecting willingness to communicate was seen between trilingual groups, which was confirmed by the findings of both quantitative and qualitative methods.
\end{abstract}

Keywords: mixed methods, willingness to communicate, bilingualism, trilingualism 


\section{Introduction}

Willingness to Communicate (WTC), which is the intention and desire to initiate communication, plays a key role in learning a second or foreign language (MacIntyre, Clément, Dörnyei \& Noels, 1998). According to McCroskey and Baer willingness to communicate (WTC) is defined as the probability of engaging in communication when free to choose to do so (as cited in Tousi \& Khalaj, 2014). It has an important role in helping the teacher, understanding learners' communication psychology as well as improving students' communication engagement in class. Some researchers (MacIntyre, Baker, Clément \& Donovan, 2003) have argued that a fundamental goal of L2 education should be the encouragement of willingness to communicate in language learning because WTC is expected to facilitate the language learning process so that higher WTC among students leads to increased opportunity for practice in L2 and authentic language use.

Consequently, the purpose of teaching English has shifted from the mastery of structure to the ability to use the language for communicative purposes. Thus, the issues of whether learners would communicate in English when they had the chance, and what would affect their willingness to communicate gain importance. Many Iranian teachers and researchers, however, have encountered problems concerning motivating learners to communicate, and are continually trying to find ways to encourage students to use the second language in different situations. So, since the goal of language teaching is to encourage learners to communicate efficiently, it is really important to understand why some learners are not motivated to speak in language classrooms. This lack of motivation will make learners lose their interest in learning the language. They will thus think they are not making any progress in their learning. The problem is worse in an EFL setting where the language learners do not have any chance to speak outside the classroom. The previous focus of learners' willingness to communicate was placed on their acts as learners enter into the conversation or initiate the talk; however, by viewing the willingness to communicate from a linguistic viewpoint, the understanding of the choices that learners make is expected to bring light to a new dimension of willingness to communicate. To this end, the present study considered the difference between bilingual and trilingual learners in their willingness to communicate in English. As the main purpose of the study, the researcher examined the difference between German and French learners in their degree of willingness to communicate in their second language (English) when they have an opportunity to communicate and focused on the differences between the factors influencing willingness to communicate in German and French learners.

\section{Review of Literature}

A glance over the literature of speaking and communication skill development in general and willingness to communicate in particular suggests some important factors that each has an influential role in the second and foreign learners' speaking skill enhancement. These factors can help the process of language learning to be accelerated and to be perceived easily. To restate them, some factors in the stated literature can affect and increase the motivation for communication in English. Proficiency level, length of studying a foreign language, the opportunity for communication with foreigners, the topic of speaking activity, self -perceived speaking confidence, etc., were found to influence EFL learners' willingness to communicate.

MacIntyre et al. (1998) proposed a pyramid model that shows the range of components potentially influencing WTC in the L2. There are six layers in the pyramid model. The first three 
layers of the model refer to those variables which have a situation-specific effect on individuals' WTC, and the next three layers include those variables with enduring influence on WTC.

Hashimoto (2002) examined affective variables as a predictor of L2 use in Japanese ESL learners' classroom. The results of the study indicated that motivation and WTC affect communication frequency in the classroom. Furthermore, the finding showed that the variables underlying WTC, including perceived competence and L2 anxiety, were the causes of WTC. Perceived competence exerted a strong influence on WTC in L2 communication and led to more L2 use. L2 anxiety was found to be a negative predictor of perceived competence and WTC, consequently.

Alemi, Daftarifard, and Pashmfroosh (2011) investigated the Impact of language anxiety and language proficiency on WTC and found that Iranian university students' WTC is directly related to their language proficiency, but surprisingly higher proficient learners showed to be less communicative than lower proficient ones outside the classroom.

Khazaei, MoeinZadeh, and Ketabi (2012) examined the effect of class size on Iranian EFL learners' willingness to communicate. The result indicated that class size can strongly affect the participation of the learners in-class discussion and WTC. Teachers in larger classes should be aware of employing more communicative strategies to encourage the students to participate and to be involved in in-class interaction.

In another study, Alemi, Tajeddin, and Mesbah (2013) investigated the relationship between WTC and individual differences. They concluded that Iranian EFL learners' WTC is somehow affected by their differences. Simic (2014) examined learners' willingness to communicate in two different countries - Austria and Serbia - and in two different school environments, namely grammar and vocational schools.

Based on the findings of his study, certain factors were seen as most influential by the majority of the participants from all four schools. The topic of the speaking activity was identified as a strong influence on speakers' willingness to communicate. This was also confirmed by the fact that the majority of the participants said that they were more willing to talk about something if they were personally interested in it. Besides, self-perceived speaking confidence of the participants was said to play a very important factor - if it is rated higher, it has a stimulating effect, and vice versa; however, regardless of how confident the participants were during speaking, their wish to practice their speaking skills could help them override their potential inhibition. Two additional factors that were ranked fourth and fifth were a wish to get a better grade, and the way they felt at the moment (i.e. their mood).

Barraclough, Christophel, and McCroskey (1988) considered the importance of a person's perception of their communicative competence by presuming that, if a person perceives themselves as less competent, they would avoid engaging in communication: It is believed that a person's selfperceived communication competence, as opposed to their actual behavioral competence, will greatly [a]ffect a person's willingness to initiate and engage in communication.

Regarding the review of the literature of trilingualism, it should be mentioned that the study of trilingualism in education has not received much attention until recently. It is only in the last two decades that we have witnessed a surge in publications, conferences, and journals that go beyond 
the teaching and learning of two languages in education (Adamson et al., 2015), and despite the large numbers of students worldwide who learn third languages, and the recognition of the particular motivational challenges this involves, up until recently few motivation researchers have been concerned with L3s. After researching motivational effects of cross-linguistic awareness, Jessner ( as cited in Henry, 2013 ) made clear that language teachers need to develop multilingual skills so that in their teaching they can identify points where languages intersect and where crosslinguistic influence is likely to be at play.

According to a research based on the role played by a second-generation woman as a mediator in her family, the linguistic analysis showed that to overcome communication breakdowns, she made full use of her competence in all three languages, Italian, Sicilian and English, and employed code-switching extensively as a conversational strategy to accommodate participants with different language abilities (Antonia, 2004).

Uribe (2015) believed that it is difficult to gain fluency in three languages, but the time and sacrifice in the long run, worth it. In his opinion, trilinguals become different people with every language they master, trilingualism could open opportunities for jobs. Trilinguals find a connection in history, art, and literature, but most importantly, their heritage. Trilinguals become smarter, those who speak more than two languages have higher cognitive thinking abilities. They appreciate cultures much more, and they also boost their memory and more importantly, trilinguals can interact and connect with more people around the globe easily. To this end, the present study aimed to determine whether learning a third language have a positive influence on learners' willingness to speak in English, and also to examine whether different L3s may have different influences on learners' willingness to communicate in their communication in English. To achieve this objective, the following research questions were posed by the researcher:

RQ1: Does learning a third language have a significant positive effect on promoting Iranian EFL learners' willingness to communicate in their L2?

RQ2: Is there any statistically significant difference between Iranian L3 French learners and Iranian L3 German learners in terms of the factors affecting their willingness to communicate in English?

\section{Method}

\subsection{Design of the study}

As willingness to communicate is a complex issue, the use of interviews suits the objectives of this study. So, the present study employed a mixed-method design to gain a rich description of the dynamic process in the participants' own terms. Also, since the effects of a treatment or intervention have not been tested in this study and a set of factors without any attempt at imposing change was examined, a descriptive method was applied.

\subsection{Participants}

Participants in this study consisted of 20 English learners and 40 trilingual learners including 20 German and 20 French learners who were selected from among four Institutes in Shiraz. The English learners were selected from Intermediate classes. The German learners were chosen from (B1) classes, and French learners were those who attended (nip1 \& nip2) classes. 


\subsection{Instruments}

- $\quad$ An Oxford Placement Test (version 2)

- Willingness to communicate questionnaire (Gutmann, 2012)

- $\quad$ A semi-structured interview consists of questions the participants were asked.

\subsection{Data collection procedure}

First of all, based on the availability of the learners, 20 English participants were selected from among Intermediate English classes from four institutes in Shiraz. The Oxford placement test was administered to the French and German learners to determine the level of English proficiency of the trilingual participants and based on the results of the test, 40 trilingual participants were selected as appropriate samples. So, 60 participants, including both bilingual and trilingual learners, were selected as the final sample of the present study.

In the second stage, the L2 WTC questionnaire was used to measure the degree of willingness among language learners and to consider and compare the differences in the factors affecting trilingual learners.

To verify the results of the quantitative part of the study, an interview protocol was prepared and used. To prepare interview questions, a group of questions related to the present study was selected based on Cetinkaya (2005) Cao, and. Philp (2006).

\subsection{Data analysis}

To analyze the quantitative data of the study, the collected data was submitted to SPSS version 20. The reliability coefficient of the WTC questionnaire using Chronbach's Alpha consistency was estimated to be 0.837 . Therefore, the WTC questionnaire was reliable.

Also, the Kaiser-Meyer-Olkin (KMO) measure of sampling adequacy was greater than 0.80 and, Bartlett's test of sphericity was significant which indicated that the relationship among variables was strong (Sig. $<0.05$ ). Both descriptive and inferential statistics were used to analyze the data. To compare the overall WTC between Iranian English learners, Iranian French learners, and Iranian German learners, a one-way ANOVA test was run. Also, comparing the distribution of votes on the scales from completely agree to completely disagree in Iranian English/German learners and Iranian English/French learners, the z-score test (with Bonferroni's method) was used.

The technique that was used to enhance the trustworthiness and credibility of the qualitative part of the present study, was peer debriefing. The peer detected whether or not the researcher had overemphasized a point, or missed a rival legitimate hypothesis, underemphasized a point, and in general did a careful reading of the data and the final report. Regarding the reliability of the study, the researcher checked for reliability through inter-rater agreement. It involves asking a (disinterested) peer to code the data and comparing the coding with the researcher's coding to determine whether they reached the same codes or different ones. The following table represents the demographic information of the interviewees. 


\section{Table 1}

Demographic Information of Interviewees

\begin{tabular}{|c|l|c|l|l|l|}
\hline No & Pseudonym & Gender & Age & Field of Study & Language \\
\hline 1 & Sara & F & 26 & Computer & French \\
\hline 2 & Ali & M & 28 & Physics & German \\
\hline 3 & Maryam & F & 32 & Law & French \\
\hline 4 & Sourena & M & 21 & Architecture & French \\
\hline 5 & Peyman & M & 29 & Biotechnology & German \\
\hline 6 & Marjan & F & 30 & Sociology & French \\
\hline 7 & Mohammad & M & 34 & Social Psychology & French \\
\hline 8 & Hamid & M & 32 & IT & German \\
\hline 9 & Sahar & F & 24 & Microbiology & German \\
\hline 10 & Navid & M & 20 & Civil Engineering & French \\
\hline 11 & Parisa & F & 19 & Economics & German \\
\hline 12 & Saba & F & 22 & Management & German \\
\hline
\end{tabular}

\section{Results and Discussion}

\subsection{Quantitative Data Analysis}

The first research question examined the difference between bilingual and trilingual learners by posing this question: "Does learning a third language have a significant positive effect on promoting Iranian EFL learners`WTC?”

Table 2 represents descriptive statistics of overall WTC for bilingual and trilingual participants.

\section{Table 2}

Descriptive Statistics for Bilingual and Trilingual Participants

\begin{tabular}{|c|c|c|c|c|}
\hline Learners & $\mathrm{N}$ & Mean & Std. Deviation & $\begin{array}{c}\text { Std. Error } \\
\text { Mean }\end{array}$ \\
\hline bilingual & 20 & 3.2175 & .51434 & .11501 \\
\hline trilingual & 40 & 3.8788 & .42470 & .06715 \\
\hline
\end{tabular}

Table 3 summarizes the results of independent samples t-test for the overall WTC of bilingual and trilingual participants. As Table 3 indicates, the Levene's test is not significant $(\mathrm{F}=0.118$, Sig.>0.05). Thus, the assumption of homogeneity of variance cannot be rejected. Then, we can use 
the results of the first row (Equal variances assumed). As shown in Table 3, there is a statistically significant difference between bilingual and trilingual learners in terms of WTC ( $t(58)=-5.295$, Sig. $<0.05)$. In other words, the overall WTC in trilingual participants is significantly more than the overall WTC in bilingual participants.

\section{Table 3}

Independent Samples T-Test for Overall WTC of Bilingual and Trilingual Participants

\section{Levene's Test for Equality of Variances}

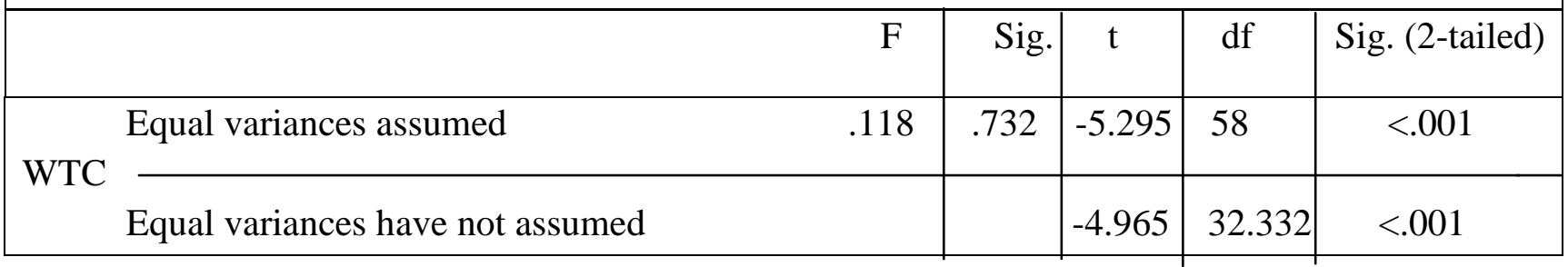

Descriptive statistics were used to compare the overall WTC between Iranian English Learners, English/French Learners, and English/German Learners.

\section{Table 4}

Descriptive Statistics for Iranian English Learners, Iranian English/French Learners, and Iranian English/German Learners

\begin{tabular}{|c|c|c|c|c|}
\hline & $\mathrm{N}$ & Mean & Std. Deviation & Std. Error \\
\hline English & 20 & 3.2175 & .51434 & .11501 \\
\hline English/German & 20 & 3.9450 & .34523 & .07720 \\
\hline English/French & 20 & 3.8125 & .49174 & .10996 \\
\hline
\end{tabular}

As shown in Table 5 there is a statistically significant difference between Iranian English learners, Iranian English/French learners, and Iranian English/German learners in terms of WTC $(\mathrm{F}(2,57)=$ 14.401, Sig. <0.05).

\section{Table 5}

ANOVA Test for Overall WTC of Iranian English Learners, Iranian English/French Learners and Iranian English/German Learners

\begin{tabular}{|c|c|c|c|c|c|}
\hline & Sum of Squares & df & Mean Square & F & Sig. \\
\hline Between Groups & 6.006 & 2 & 3.003 & 14.401 & $<.001$ \\
\hline Within Groups & 11.885 & 57 & .209 & & \\
\hline Total & 17.891 & 59 & & & \\
\hline
\end{tabular}

It can be concluded that at least one or two of the subscale means are significantly different from the others (or that at least two of the subscale means are significantly different from each other). 
However, to determine which WTC subscales are significantly different from each other, a posthoc test was used. Table 6 reports the results of the posthoc test (Duncan and Tukey).

\section{Table 6}

Post hoc Tests for Overall WTC of Iranian English Learners, Iranian English/French Learners and Iranian English/German Learners

Subset for Alpha $=0.05$

\begin{tabular}{|c|c|c|c|c|}
\hline Method & Group & N & \multicolumn{2}{|c|}{} \\
\hline & & & 1 & 2 \\
\hline \multirow{3}{*}{ Tukey HSD } & English & 20 & 3.2175 & \\
\hline & English/French & 20 & & 3.8125 \\
\hline & Sig. & & 1.000 & .632 \\
\hline & English & 20 & 3.2175 & \\
Duncan & English/French & 20 & & 3.8125 \\
\hline & English/German & 20 & & 3.9450 \\
\hline & Sig. & & 1.000 & .363 \\
\hline
\end{tabular}

Table 6 indicates that the overall WTC in Iranian English learners is significantly lower than the overall WTC in Iranian English/French learners and Iranian English/German learners. Also, the overall WTC in Iranian English/French learners is equal to the overall WTC in Iranian English/German learners (Sig.>0.05).

As it was stated, there was not a statistically significant difference between German and French learners concerning the degree of their willingness to communicate in their L2. However, the researcher examined and compared the factors influencing willingness to communicate between these two groups in detail.

Table 7 and 8 represents the number of English / German and English /French learners who identified the level of their agreement with 20 statements.

Table 7

The Overall WTC of Iranian English/German Learners

\begin{tabular}{|c|c|c|c|c|c|}
\hline Statement & $\begin{array}{l}\text { Completely } \\
\text { Agree }\end{array}$ & Agree & Neutral & Disagree & $\begin{array}{c}\text { Completely } \\
\text { Disagree }\end{array}$ \\
\hline 1. I need to feel prepared to speak freely & 8 & 8 & 3 & 1 & - \\
\hline 2. I like to talk about a topic if I am interested in it & 9 & 11 & - & - & - \\
\hline 3. I am confident when speaking English & 8 & 7 & 2 & 1 & 2 \\
\hline 4. I like to Speak English & 13 & 6 & 1 & - & - \\
\hline 5. I like to speak English with foreigners & 13 & 6 & 1 & - & - \\
\hline 6. I feel comfortable speaking to native speakers of English & 7 & 9 & 2 & 2 & - \\
\hline
\end{tabular}




\begin{tabular}{|lccccc|}
\hline 7. I like to do presentation on my own & 3 & 8 & 3 & 2 \\
\hline 8. In my English class, I need to feel relaxed to speak freely & 5 & 7 & 6 & 1 & 1 \\
\hline 9. I am more willing to speak when I know nobody laugh at me & 7 & 7 & 5 & - & 1 \\
\hline 10. I think mistakes are signs of learning & 7 & 8 & 3 & 2 & - \\
\hline 11. For me, preparation is the key for successful speaking & 6 & 7 & 4 & 2 & 1 \\
\hline 12. I think an interesting topic is important for speaking & 9 & 7 & 3 & 1 & - \\
\hline 13. I am satisfied with my speaking skills & 5 & 8 & 4 & 2 & 1 \\
\hline 14. I feel at ease when speaking in my English class & 3 & 10 & 4 & 3 & - \\
\hline 15. I feel confident when I speak to my peers & 5 & 8 & 5 & 1 & 1 \\
\hline 16. I enjoy speaking in groups & 4 & 11 & 6 & - & - \\
\hline 17. I enjoy speaking in relaxing atmosphere & & & & & \\
\hline 18. I see the class as a place to practice my speaking skills & 5 & 11 & 3 & 1 & - \\
\hline 19. I like to speak even if I make mistakes occasionally & 5 & 4 & 6 & 5 & - \\
\hline 20. I feel comfortable speaking in English to my close friends & 7 & 6 & 6 & - & 1 \\
\hline
\end{tabular}

Table 8

The Overall WTC of Iranian English/French Learners

\begin{tabular}{|c|c|c|c|c|c|}
\hline Statement & $\begin{array}{r}\text { Completely } \\
\text { Agree }\end{array}$ & Agree & Neutral & I Disagree & $\begin{array}{c}\text { Completely } \\
\text { Disagree }\end{array}$ \\
\hline 1. I need to feel prepared to speak freely & 10 & 6 & 3 & 1 & - \\
\hline 2. I like to talk about a topic if I am interested in it & 11 & 6 & 2 & 1 & - \\
\hline 3. I am confident when speaking English & 6 & 7 & 6 & 1 & - \\
\hline 4. I like to Speak English & 13 & 5 & 1 & - & 1 \\
\hline 5. I like to speak English with foreigners & 11 & 6 & 3 & - & - \\
\hline 6. I feel comfortable speaking to native speakers of English & 6 & 5 & 5 & 4 & - \\
\hline 7. I like to do presentation on my own & 6 & 8 & 4 & 1 & 1 \\
\hline 8. In my English class, I need to feel relaxed to speak freely & 7 & 10 & 2 & 1 & - \\
\hline 9. I am more willing to speak when I know nobody laugh at me & 9 & 9 & - & 1 & 1 \\
\hline 10. I think mistakes are signs of learning & 10 & 4 & 3 & 1 & 2 \\
\hline 11. For me, preparation is the key for successful speaking & 8 & 7 & 4 & 1 & - \\
\hline
\end{tabular}




\begin{tabular}{|c|c|c|c|c|c|}
\hline 12. I think an interesting topic is important for speaking & 9 & 8 & 2 & 1 & - \\
\hline 13. I am satisfied with my speaking skills & 5 & 6 & 7 & 2 & - \\
\hline 14. I feel at ease when speaking in my English class & 6 & 5 & 7 & 2 & - \\
\hline 15. I feel confident when I speak to my peers & 5 & 10 & 3 & - & 2 \\
\hline 16. I enjoy speaking in groups & 6 & 10 & 4 & - & - \\
\hline 17. I enjoy speaking in a relaxing atmosphere & 8 & 11 & 1 & - & - \\
\hline 18. I see the class as a place to practice my speaking skills & 10 & 7 & 3 & - & - \\
\hline 19. I like to speak even if I make mistakes occasionally & 3 & 4 & 7 & 3 & 3 \\
\hline 20. I feel comfortable speaking in English to my close friends & 8 & 9 & 2 & 1 & - \\
\hline
\end{tabular}

\subsection{Qualitative Data Analysis}

In the present study, besides using a questionnaire and quantitative analysis of data, some interviews were used to confirm and increase the accuracy of data and quantitative results. Accordingly, a group of English/ German learners and English/ French learners were interviewed.

Having analyzed the data derived from the interviews, the researcher came up with several factors influencing willingness to speak in both groups. The researcher of the present study transcribed the recordings of individual interviews to familiarize herself with the data at hand. Transcriptions were generated from the recorded interview data. Once transcriptions have been completed, the researcher read the transcripts several times, looking for salient and recurring ideas emerging from the data to present them in the form of some codes. Moreover, while analyzing the data, the researcher looked for the factors the German and French learners described as having an impact on their willingness to speak, as well as those that emerged from the interview data. Once the codes were developed, the researcher attempted to put similar codes together to arrive at categories or themes or findings. As an example, codes concerning the topic (topic preparation, topic interest, topic familiarity) were categorized under the influence of topic or (speaking with close friends, foreigners, or native speakers) came under the theme of relationship with interlocutors. Once the data were analyzed, the researcher summarized the data and then interpreted them.

\subsubsection{Topic of Discussion}

A factor that both German and French learners found to have a great influence on their degree of willingness to speak was a topic of discussion. Topic interest, topic familiarity, and topic preparation were among those features that were considered as important elements for increasing willingness to communicate for both groups. Topic familiarity was equally important for all participants. They believed that if they have information about a topic, they would be more willing to talk about it. Ali, for example, stated that the more he is familiar with a topic, the more he is willing to talk about it.

If I have a piece of ample knowledge about a topic, I am more intended to talk about it. But when I don't have enough information, I don't like to speak, and I prefer to stay silent. 
Topic interest was another feature of a topic that was important for both groups. Most participants stated that they are willing to communicate about a topic in which they are interested. Mohammad, for example, argued that:

If the topic is interesting, I like to talk more about it, but if the topic is not interesting to me, I am not willing to talk about it, for example, I am more interested in topics related to movies, music or sport especially football, so when there is an opportunity, I talk a lot about these topics.

\subsubsection{Relationship with Interlocutors}

Familiarity with interlocutors is another factor that most of the participants refer to as an influencing factor in their willingness to communicate. Seven of them believed that they were more intended to speak with a person who they know well. The main reason they expressed was the relaxing sense they had when they talked with a person whom they were familiar with. An example is Sara who stated:

The person I'm talking with and our relationship is an important factor to me. If that person is familiar with me, and if he or she is my close friend, I feel more comfortable and motivated to speak.

Most of the participants, ( 8 out of 12), were also motivated to talk with foreigners and especially native speakers. They expressed the fact that when they talk with foreigners, they feel more comfortable because the foreigners don't pay a lot of attention to grammatical points and the speakers don't need to be worried about their accuracy all the time.

To tell you the truth, I am more comfortable and relaxed when I talk with native speakers. I feel free when I communicate with them because I just need to convey meaning. I am not so worried about the correctness of grammar when I talk with a native speaker.

Asking about the sex of the interlocutors, the researcher received some contradictory responses. Some respondents were more comfortable with interlocutors from their same-sex, while others were motivated to communicate with the interlocutors from the opposite sex.

I am intended to talk with girls; I like to know whether the opposite sex can interact with me very well or not, so I prefer to communicate with the opposite sex (Sourena).

In contrast, Marjan was more willing to talk with a person of the same sex.

I am more comfortable when I speak to a woman. I have a lot of things in common with other women and can talk with them about issues that are related to our sex.

Four participants of the study (Saba, Maryam, Parisa, Hamid), had a similar idea to that of Marjan, three other participants, namely Peyman, Navid, and Sahar had the same idea as that of Sourena, and the other three did not consider sex as an important factor in their willingness to speak.

In response to the question related to the age of the interlocutors, some of the interviewees from both groups preferred to talk with younger interlocutors, and some others were intended to communicate with older ones. Five participants believed that the age of the interlocutor does not matter to them. The interviewees, Sourena, Parisa, Navid, and Sara stated that they are more interested to talk with a person who is older than them because they have more opportunities to 
learn from older learners. They expressed some reasons for this intention, including the chance to learn from older students (Parisa, Sara, Navid), and gaining knowledge from their experience ( Sourena). Three other participants believed that they are more willing to communicate with younger students because of the opportunity of receiving energy from them (Saba), and taking higher risks to talk in a different situation (Hamid, Marjan).

\subsubsection{Grading}

This factor examines learners' degree of willingness to speak when they know their speaking is being graded. Only two participants were intended to be evaluated by the teacher and one participant (Marjan) believed that the score students get, can be a good criterion for their speaking ability.

Why not? I am willing to be evaluated by the teacher while speaking... of course, I'm sometimes scared of the scores but still, I want to know how my speaking is.

Two other participants (Sara and Maryam) also contended that the only way to get to know if one is improving or not is to be assessed and marked by the teacher.

I think the grades the teacher assigns, create a sense of motivation as well as competition among us, which makes us attempt more to be better than others (Sara).

The other nine respondents, in contrast, held different views in this regard. Navid, for example, stated that:

I think being graded has more harm than benefits. In my opinion, being scored is a stressful activity that prevents me from displaying my full potentials.

Sometimes, I believe that most students are afraid of being negatively evaluated and judged by the teacher, which may finally lead to a failing score (Ali).

In short, learners' knowing the fact that they are being graded while speaking causes anxiety, which will prevent them from showing their real speaking ability i.e., learners' willingness to communicate decreases if they know they are being formally evaluated, that's why dynamic assessment has become a common way of assessing learners in recent years.

\subsubsection{Correction}

There was a considerable number of participants from both groups (5 learners) who were uncertain about the role of this factor in their willingness to communicate, which raises a reasonable doubt about the general status of mistakes in language classrooms. One could argue that this uncertainty about the role of mistakes refers to different approaches and methods of language teaching. The way teachers and instructors react to learners` mistakes and also their way of error correction may also be a reason for uncertainty about this statement in both groups. Four students were intended to speak even if they make mistakes and considered mistakes as signs of learning, Sourena, for example, argued that:

The only thing that is important to me is to convey the meaning, I don't care about the correction of my speech, because I think by talking more and more my speaking will gradually improve. 
The other three participants considered the correctness of speech as an important issue. Saba, for example, stated that:

For me, the grammar of my sentences is very important; so I try to choose sentences and structures that I'm sure they are correct. I prefer to be silent rather than making a mistake."

I always try to speak correctly both in grammar and content, so before I speak I try to prepare everything carefully in mind and then start to speak (Mohammad).

\subsubsection{Classroom Atmosphere}

A positive, relaxing, and supportive atmosphere can be a prerequisite for successful language learning. Classroom atmosphere can be identified as a combination of several components from MacIntyre and associates' (1998) pyramid model - intergroup attitudes, social situation, and intergroup climate, which makes it a complex factor. Most of the participants agreed that they enjoy speaking in a relaxing atmosphere.

I think everybody needs to be relaxed in class. The class should have a positive atmosphere. In this situation, all the students will be encouraged and motivated to speak. (Maryam).

Most of the respondents in both groups agree that the classroom atmosphere can either facilitate or impede their participation. Peyman, for example, stated that:

I am willing to speak more in an environment that is friendly enough so that I feel secure and relaxed and it makes me more encouraged to speak.

One reason could be the fact that in a relaxing environment, learners get to know and trust each other better. This would contribute to more participation.

In a relaxing environment, I feel secure enough to express myself and I am not afraid of making mistakes and then being ridiculed (Sara).

I feel more willing to speak in a stress-free environment where there is a friendly rapport between us (Navid).

It seems that being judged and laughed by others hindermost of the participants from speaking. It may be influenced by Iranian culture in which most people are always afraid of being judged by others, so they try not to do something until they are in an ideal and perfect status related to that issue.

I want to be sure that even if I make a mistake or run into difficulty, others will respond in a friendly and encouraging manner. I am more willing to speak when I know nobody will laugh at me (Parisa).

\subsubsection{Teachers' Role}

Most of the interviewees stated that the critical role the teacher plays in making learners willing or unwilling to speak cannot be ignored. Hamid, for example, argued that an effective teacher should motivate all learners and involve them in a discussion. 
I think one of the most important skills that a teacher may have is to involve all students in different speaking activities. Teachers need to apply some strategies to motivate and encourage students to be engaged in discussions.

I think the teacher should involve all students more and more in discussions, and he/she should motivate them to practice speaking by asking them questions and requesting their answers and opinions (Saba).

Ali, on the other hand, blamed some teachers for making students unwilling to speak. He contended that:

Some teachers have dictator-type attitudes and create a stressful atmosphere in the class, which makes everybody afraid of speaking because of the fear of making mistakes and losing their reputation.

Mohammad held a similar belief by saying that:

Some teachers talk all the time and don't give enough time to students to speak. Their class is usually full of stress and students are afraid of speaking because they know if they speak and then make a mistake, something bad may happen.

\subsubsection{Personality}

Personality was another important factor that was considered to have a great role in determining the degree of willingness to communicate from the participants' point of view. Marjan showed her agreement to the importance of this factor by saying that:

Yes, no doubt! I think personality is a very important factor in determining the degree of willingness to speak. Some students are shy by nature and prefer to be silent, but some others are very active and like to talk all the time.

Ali, too, believed that personality is an important factor that makes some students willing to speak while others are unwilling. He also added the effect of the learners' perceived competence.

A very important factor is personality. Some students are very shy, some others are not. So they speak more. Also, some students do not have enough confidence in their abilities and they don't believe themselves so they prefer to be reticent.

Sara mentioned learners' shyness, self-confidence, and their self-rated speaking ability as three important factors in this regard:

One factor is shyness. Some other students do not have enough self-confidence to speak or maybe they think their speaking is not good and that they are weak, so they prefer to be silent.

\subsubsection{Task Type}

Task type, i.e., speaking individually, in pairs, or groups is another factor that the interview respondents described as influencing their willingness to speak in class. Most of the respondents (ten out of twelve) appeared to be more willing to speak in pairs or groups than individually. Sahar is more intended to speak in pairs and groups because she feels more comfortable and relaxed doing so rather than speaking individually while everybody is listening. 
I prefer to speak with my classmates, in pairs or groups, because I have less stress, and I'm more comfortable, but if I have to speak individually, I feel everybody is looking and listening to me, so I get anxious, and it hinders me from speaking freely.

Other interviewees declared different reasons including having the chance to learn from others (Maryam, Sara) or comparing their speaking skills with their classmates (Navid, Sourena). However, Ali and Peyman, two other participants in the interview, had a different view in this regard. Ali stated this view by arguing that:

I am more willing to speak individually because I have more time to discuss a topic. I think when in groups, the time allotted is naturally shared among the members of the group and thus a limited amount of time is given to me to speak!

When asked to express their degree of willingness to present a lecture in front of the class, nearly all the respondents (11 out of 12) expressed a very low willingness to perform such an activity. Instead, they preferred to give a lecture to their classmates in pairs or groups rather in front of all the class. Parisa, as an example, was not willing to present a lecture in front of the class.

Presenting a lecture in front of the class is an activity that reduces my self-confidence because I have a very bad feeling when I see that everybody is staring at me and I am being watched closely.

The results of data analysis derived from interviews with learners are presented in Table 9.

\section{Table 9}

Codes Identified in Interviews with Learners Using NVivo Software

\begin{tabular}{|c|c|c|}
\hline $\begin{array}{l}\text { Code } \\
\text { Frequency }\end{array}$ & Identified Codes & Main Themes \\
\hline 10 & Talking about a topic if they are interested in it & \multirow[t]{5}{*}{ Topic of Discussion } \\
\hline 11 & An interesting topic is important for speaking & \\
\hline 9 & $\begin{array}{l}\text { Preparation is the key for successful and free } \\
\text { speaking }\end{array}$ & \\
\hline 9 & $\begin{array}{l}\text { Having enough information about a topic makes } \\
\text { them interested to talk about it }\end{array}$ & \\
\hline 10 & $\begin{array}{l}\text { Preparing something before a class, helps learners to } \\
\text { speak very well without mistake }\end{array}$ & \\
\hline 7 & $\begin{array}{l}\text { Feeling comfortable speaking in English to close } \\
\text { friends }\end{array}$ & \multirow[t]{7}{*}{$\begin{array}{l}\text { Relationship with } \\
\text { Interlocutors }\end{array}$} \\
\hline 8 & Preferring to speak English with foreigners & \\
\hline 9 & $\begin{array}{l}\text { Feeling comfortable speaking with native speakers of } \\
\text { English }\end{array}$ & \\
\hline 4 & Feeling confident when speaking to peers & \\
\hline 5 & $\begin{array}{l}\text { Learning better from and feeling more comfortable } \\
\text { speaking with the same sex }\end{array}$ & \\
\hline 4 & $\begin{array}{l}\text { Willing to communicate with a person of the } \\
\text { opposite sex }\end{array}$ & \\
\hline 3 & $\begin{array}{l}\text { Willing to speak with a younger student because of } \\
\text { receiving more energy and self-confidence }\end{array}$ & \\
\hline
\end{tabular}




\begin{tabular}{|c|c|c|}
\hline 4 & $\begin{array}{l}\text { Preferring to communicate with an older speaker } \\
\text { because of learning from an older one }\end{array}$ & \\
\hline 2 & $\begin{array}{l}\text { Being intended to speak even if making mistakes } \\
\text { occasionally }\end{array}$ & \multirow[t]{2}{*}{ Correction } \\
\hline 2 & Making a mistake is a sign of learning & \\
\hline 2 & Willing to be evaluated by the teacher & \multirow[t]{2}{*}{ Grading } \\
\hline 1 & $\begin{array}{l}\text { Scores can be a good measure of one's speaking } \\
\text { ability }\end{array}$ & \\
\hline 10 & Enjoy speaking in a relaxing atmosphere & \multirow[t]{4}{*}{ Classroom atmosphere } \\
\hline 8 & The class should have a positive atmosphere & \\
\hline 6 & $\begin{array}{l}\text { Learners' degree of participation increases in a } \\
\text { relaxing environment }\end{array}$ & \\
\hline 3 & $\begin{array}{l}\text { In a relaxing environment, learners get to know and } \\
\text { trust each other better }\end{array}$ & \\
\hline 6 & It is the teacher's job to create a positive atmosphere & \multirow[t]{5}{*}{ Teacher's Role } \\
\hline 5 & $\begin{array}{l}\text { An effective teacher pays equal attention to all } \\
\text { students }\end{array}$ & \\
\hline 5 & A good teacher motivates all students to speak & \\
\hline 3 & Some teachers have dictator-type behaviors & \\
\hline 2 & Some teachers create a stressful atmosphere in class & \\
\hline 10 & Personality is an important factor & \multirow[t]{7}{*}{ Personality } \\
\hline 11 & $\begin{array}{l}\text { Personality makes some students willing to speak } \\
\text { while some others unwilling }\end{array}$ & \\
\hline 9 & $\begin{array}{l}\text { Being shy and prefer to be silent makes learners less } \\
\text { willing to speak }\end{array}$ & \\
\hline 9 & $\begin{array}{l}\text { Being active and like to talk all the time to improve } \\
\text { the degree of WTC }\end{array}$ & \\
\hline 8 & $\begin{array}{l}\text { Being confident and believe themselves helps } \\
\text { learners to develop their speaking abilities }\end{array}$ & \\
\hline 3 & $\begin{array}{l}\text { Being afraid of others' judgment impede learners } \\
\text { from speaking }\end{array}$ & \\
\hline 5 & $\begin{array}{l}\text { Being anxious makes one less willing to } \\
\text { communicate }\end{array}$ & \\
\hline 1 & $\begin{array}{l}\text { Willing to give a presentation in English in front of } \\
\text { classmates }\end{array}$ & \multirow[t]{4}{*}{ Task Type } \\
\hline 6 & Enjoying speaking in groups & \\
\hline 2 & Preferring to do presentations on their owns & \\
\hline 4 & $\begin{array}{l}\text { Preferring to speak in pairs because of having less } \\
\text { stress }\end{array}$ & \\
\hline
\end{tabular}

\section{Discussion}

The first research question examined the effect of learning a third language on promoting Iranian EFL learners' willingness to communicate in L2. According to the result of Table 3, there was a significant difference between bilingual and trilingual learners in terms of their willingness to communicate. That is, the overall WTC in trilingual learners was significantly more than the overall WTC in bilingual learners.

One potential reason for this finding is that learning additional languages promotes understanding and reduces fear and misunderstanding. Language is not just a means of 
communication, but a door to whole other ways of thinking, and the more of such doors, the better. In other words, the more languages we learn, the more opportunities we find to speak in different situations, the more our fear and anxiety decrease, and the more willing we are to communicate.

The second research question examined the main purpose of the study and considered the difference between Iranian French and German learners in terms of willingness to communicate in English and the factors influencing their willingness to communicate. The result of the present study indicated that the overall WTC in Iranian English/French learners was equal to the overall WTC in Iranian English/German learners. Examining the factors influencing willingness to communicate in French and German learners, the results indicated that there was not any statistically significant difference between German and French learners in terms of their willingness to communicate. However, there were some slight differences between these two groups in their willingness to communicate in different situations. Asking about the participants' attitudes towards speaking English in class, only $15 \%$ of German participants completely agreed with the statement. The percentage was twice in the French group. On the other hand, 50\% of German learners agreed with the statement, which in the French group the percentage was half, i.e. (25\%). Also, compared with the French group, it seems that German learners feel more comfortable speaking with native speakers of English. Regarding the embarrassment factor, the percentage of votes on the neutral scale in German learners was significantly higher than the percentage of votes on this scale in the French group. The results of the interview also indicated that in both groups the participants stated that they enjoy speaking in groups and pairs rather than individually. By considering all responses meticulously, however, it became clear that the French learners of the present study were more comfortable speaking in pairs or groups and the German learners were, to some extent, less willing to speak in groups. This may probably be related to the strict and harsh nature of the German language on one hand, and the soft and friendly nature of the French language on the other hand!

In general, pair and group activities are preferred to speaking individually. Cetinkaya (2005) expressed that the individuals in his study preferred to speak in dyads, or groups rather than speaking individually in front of a large group of people. Also, Cao and Philp (2006) contended that running a pair-or group work in class gives individuals greater opportunities to speak than in the case of speaking individually. Indeed, such activities create a more relaxed atmosphere in the classroom, reduce anxiety, and thus result in an increase in both quantity and quality of practice (Ur, 2000).

Both German and French learners considered preparedness as an important factor affecting their willingness to communicate. The result of this study is in line with that of Riasati (2012) who stated that one of the factors that were found to exert an influence on learners' degree of willingness to speak English is topic preparation. Also, most of the participants were more motivated to talk about a topic in which they are interested. As Kang (2005) contended, some particular topics may bring about greater "responsibility" to involve; that is, one feels the need to discuss a topic because it is intrinsically and instrumentally interesting to him or her.

Regarding correction and grading, most of the participants preferred remaining silent rather than making mistakes while some others intended to speak without any fear of making mistakes. Similar to this finding is Lisa (2006) who reported that 85 percent of the participants in her study were more willing to talk only if they were sure their answer was correct. When asked about grading, the researcher received some contradictory responses. Some were intended to be evaluated 
by the teacher and most were not intended to be judged and evaluated by the teacher. The result is in line with that of Riasati (2012), as he stated that learners' knowing the fact that they are being graded while speaking causes anxiety, which will prevent them from showing their real speaking ability. However, when the learners consider mistakes as a sign of learning, this shift would decrease the threat to students' faces, as it enables the students to get over possible mistakes faster without any overly explicit correction by the teacher. The results are also in line with Jamshidnejad's (2010) study, who reported that the participants of his study were over-concerned with making mistakes and being negatively evaluated by others and that, in general, the fear of making mistakes increases the chance of losing one's face.

The role of the teacher was also among those factors that both groups considered as a very important factor in determining the degree of their willingness to communicate. Some studies carried out by Sun (2008), Cao (2009), and Zeng (2010) confirmed the important role of the teacher in facilitating or inhibiting learners' participation.

Regarding the personality factor, most students considered shyness as an impeding factor. It was expected that the participants of the study mention shyness and personality as an important factor affecting their willingness to speak. Because as it was stated by Riasati (2012) Iranian language learners are highly sensitive to the judgment of other students on their performance and therefore avoid risk-taking situations. Such predisposition influences their willingness to speak to a great extent. Chu (2008), too argued that shy students tend to feel more anxiety in language classrooms. This anxiety makes them less willing to communicate.

Someone's personality cannot be changed. The researcher, however, believes that learners' characteristics can be modified by giving them some tasks and exercises, and also by providing them with some opportunities to involve in different speaking situations, so by talking more and more to other peers and interlocutors the shyness may, to some extent, be reduced.

\section{Conclusion}

The result of the present study indicated that in general, trilingual learners were more willing to communicate. However, findings obtained from quantitative and qualitative data indicated neither significant difference in degree nor in the factors affecting the willingness to communicate in two groups of trilingual learners, namely, English/ German and English/French learners.

The current study focused on the foreign language classroom setting. So the classroom environmental factors identified as influencing willingness to speak are classroom specific, such as task type, topic, teacher, classroom atmosphere and grading, and correctness of speech.

As demonstrated in the study, willingness to speak is influenced by a range of factors. It may be due to the complexity of both WTC and the factors that influence it. It may also be because, all of the factors discussed in this paper were highly subjective, and vary from one learner to another. So, teachers should be aware of the factors that could encourage or discourage communication among learners. Therefore, language teachers must promote factors that facilitate communication and remove those that impede communication. The researcher of the study suggests that Iranian English teachers should try to make a positive classroom environment and make efforts to engage students in different communication activities, and carry out investigations in their classes 
to understand and find the factors that might increase or decrease language learners` desire to initiate communication in language classrooms.

The results of the study also demonstrated that different learners displayed different behaviors according to various contexts. As an example, some were more willing to speak with their teacher, while others preferred to speak in pairs or close friends, and others liked to speak in groups. The findings then support the necessity of the presence of different activities in language classrooms, so, the teacher must apply both group and pair activities as well as individual activities. That is, there is no unique methodology that meets all student's need and learners behave differently in different situations and also have different strategies for learning the language. So, such differences must be taken into consideration while planning teaching and learning activities. The topic of discussion was another factor that nearly all participants were considered as a vital factor in making them active or silent in the classroom. The participants clearly stated that they prefer to talk about the topic they are prepared to speak, they are interested in, and they are familiar with. So, the teacher must be familiar with the students' zone of interest, also should provide them with some opportunities to prepare themselves, i.e., to give them time to get prepared and to become familiar with the topic. Kang (2005) suggested brainstorming, taking a survey, and getting learners to propose discussion topics as the techniques teachers can adopt to identify the topics learners prefer to discuss.

Also, learners must be aware of this secret that the only way to learn a second/foreign language is through practice. They must be aware of this fact that the more they practice and the more they expose themselves to different languages, the greater will be the chance of success in learning the language. That is why, based on the findings of the present study, trilingual learners were more willing to communicate in different situations. Trilingual learners are more likely to practice both their third and second languages outside the classroom because their self-confidence is boosted, they feel more confident and skilled when speaking, so they start to speak more often, and the more they speak, the more willing they would be to communicate. They prefer to communicate and enjoy speaking with native speakers rather than to learn technical skills. Thus, Iranian EFL teachers should bear in mind that providing the learners with situations in which they can speak with native speakers of English can promote learners' willingness to communicate. The findings of the study also confirmed that learning more languages develop understanding and decrease fear and misunderstanding. In other words, the more languages we learn, the more opportunities we find to speak in different speaking situations, the more our fear of being ridiculed decreases, and the more willing we are to communicate. As MacIntyre, Baker, Cle'ment and Conrod, (2001) contended, a more successful language learner is the one who is more willing to communicate in language classrooms. They further contended that a higher degree of willingness among students leads to more opportunities for language practice and language use, which is expected to facilitate the language learning process. The findings of the present study revealed some factors that contribute to a willingness to speak in language classrooms. These findings may help teachers to encourage learners to learn a third language as a means of increasing their intention for initiating communication. They can also consider the results of the present study, and examine the different factors that might increase or decrease language learners' opportunities and readiness to communicate in a different situation and work on those elements that have a positive impact on learners`intention to initiate communication. 


\section{Acknowledgments}

The author would like to express her gratitude to Dr. Bavali for his boundless knowledge and excellent guidance through the process of writing this paper, and to language learners who contributed to the work as the participants of the study.

\section{References}

[1] Adamson, B., Ba, H., Cao, Y., Ding, H., Dong, F., Feng, A. \& Zhu, Q. (2015). Trilingualism in education at the crossroads. In A. Feng, B. Adamson (Eds). Trilingualism in education in China: Models and challenges. (pp. 243-258). Springer. https://doi.org/10.1007/978-94-0179352-0_11

[2] Alemi, M., Daftarifard, P., \& Pashmforoosh, R. (2011). The Impact of language anxiety and language proficiency on WTC in EFL context. Cross-cultural Communication, 7(3), 150166.

[3] Alemi, M., Tajeddin, Z., \& Mesbah, Z. (2013). Willingness to communicate in L2 English: Impact of learner variables. Journal of Research in Applied Linguistics, 4(1), 42-61.

[4] Antonia, R. (2004). Trilingual women as language mediators in the family [Case study]. ERIC database.

[5] Barraclough, R. A., Christophel, D.M. \& McCroskey, J.C. (1988). Willingness to communicate: A cross-cultural investigation. Communication Research Reports, 5(2), 187-192.

[6] Cao, Y., 2009. Temporal fluctuation in situational willingness to communicate in a second language classroom. New Zealand Studies in Applied Linguistics, 12(2), 1-6.

[7] Cao, Y. and J. Philp, 2006. Interactional context and willingness to communicate: A comparison of behavior in whole class, group, and dyadic interaction. System, 34, 480-493.

[8] Cetinkaya, Y.B., 2005. Turkish college students' willingness to communicate in English as a foreign language [Unpublished Doctoral dissertation]. Ohio State University.

[9] Chu, H.R., 2008. Shyness and EFL learning in Taiwan: A study of shy and non-shy college students' use of strategies, foreign language anxiety, motivation, and willingness to communicate [Unpublished Doctoral dissertation]. University of Texas, Austin.

[10] Hashimoto, Y. (2002). Motivation and willingness to communicate as predictors of reported L2 use: The Japanese context. Second Language Studies, 20(2), 29-70.

[11] Henry, A. (2013). The motivational effects of cross-linguistic awareness: Developing third language pedagogies to address the negative impact of the L2 on the L3 self-concept. Innovations in Language Learning and Teaching, 1(8), 1-19.

[12] Jamshidnejad, A. (2010). The construction of oral problems in an EFL context. Studies in Literature and Language, 1(6), 8-22.

[13] Kang, S. J. (2005). Dynamic emergence of situational willingness to communicate in a second language. System, 33, 277-292. 
[14] Khazaei, Z. M., Moeinzadeh, A., \& Ketabi, S. (2012). Willingness to communicate in Iranian EFL learners: The effect of class size. English Language Teaching, 5(11), 181-187.

[15] Lisa, L. (2006). The relationship among teachers' verbal and non-verbal immediacy behaviors and students' willingness to speaking English in central Taiwanese college classrooms [Unpublished Doctoral dissertation]. Oklahoma.

[16] MacIntyre, P.D., S.C. Baker, R. Cle'ment and S. Conrod. (2001). Willingness to communicate, social support, and language learning orientations of immersion students. Studies in Second Language Acquisition, 23(3), 369-388.

[17] MacIntyre, P., Baker, S. C., Clement, R., \& Donovan, L. A. (2003). Sex and age effects on willingness to communicate, anxiety, perceived competence, and L2 motivation among junior high school French immersion students. Language Learning, 52(3), 537-564.

[18] MacIntyre, P.D., Dornyei, Z., Clement, R, \& Noels, K.A. (1998). Conceptualizing willingness to communicate in an L2: A situational model of L2 confidence and affiliation. The Modern Language Journal, 82(4), 545-562.

[19] Riasati, M. J. (2012). EFL learners' perception of factors influencing willingness to speak English in language classrooms: A qualitative study. World Applied Sciences Journal, 17(10), 1287-1297.

[20] Sun, Y. F. (2008). Motivation speaks: Perception and attitude of non-English major students in Taiwan [Unpublished Doctoral dissertation]. Indiana University.

[21] Tousi, M., \& Khalaj, H. (2014). The impact of willingness to communicate on Iranian EFL learners speaking ability. International Research Journal of Applied and Basic Science, 8(1), 1866-1869.

[22] Ur, P. (2000). A course in language teaching: Practice and theory. Foreign Language Teaching and Research Press.

[23] Uribe, D. (2015, Oct 27). 10 Awesome benefits of being trilingual. The Odyssey. https://www.theodysseyonline.com/trilngua

[24] Zeng, M., 2010. Chinese students' willingness to communicate in English in Canada [Unpublished Doctoral dissertation]. University of Windsor. 